DOI: https://doi.org/10.32836/2521-666X/2020-68-2

УДК 339.9:338.46

\title{
Грабар М.В.
}

кандидат економічних наук, доцент кафедри туризму,

Державний вищий навчальний заклад

«Ужгородський національний університет»

Кашка М.Ю.

кандидат історичних наук, доцент кафедри туризму,

Державний вищий навчальний заклад

«Ужгородський національний університет»

Hrabar Maryna, Kashka Mariya

State Higher Educational institution

«Uzhhorod National University»

\section{ТУРИСТИЧНА ІНДУСТРІЯ УГОРЩИНИ: \\ КЛЮЧОВІ ПОКАЗНИКИ УСПІШНОГО РОЗВИТКУ}

\section{HUNGARY TOURIST INDUSTRY: KEY INDICATORS OF SUCCESSFUL DEVELOPMENT}

У статті розглянуто туристичну індустрію Угорщини. Країна посідає 48-му позицію за індексом конкурентоспроможності туризму. Встановлено, щчо туризм є стратегічним сектором економіки Угорщини, тому уряд підтримує розвиток галузі. Державні ініціативи спрямовуються на зростання загального внеску угорського туризму у ВВП ыз нинішніх $10 \%$ до $16 \%$ у майбутньому. Виявлено, що угорська система оподаткування підтримує туризм зі зниженою ставкою ПДВ на послуги розмішення. Розвиток внутрішнього туризму ініціюється на основі програми карти відпочинку для працівників. Сформовано перелік заходів, на яких грунтується державна програма розвитку туризму Угорщини (боротьба з сезонністю, доступність, підтримка високоякісних послуг, охорона культурної спадщини, поліпшення освіти в галузі туризму, таргетинг). Досліджено статистичні показники туризму Угорщзини.

Ключові слова: туризм, Угорщина, туристичні потоки, державне управління, показники. 
В статье рассмотрена туристическая индустрия Венгрии. Страна занимает 48-ю позицию по индексу конкурентоспособности туризма. Установлено, что туризм является стратегическим сектором экономики Венгрии, поэтому правительство поддерживает развитие отрасли. Государственные инициативы направлены на рост общего вклада венгерского туризма в ВВП с нынешних 10\% до 16\% в будущем. Выявлено, что венгерская система налогообложения поддерживает туризм с пониженной ставкой НДС на услуги размещения. Развитие внутреннего туризма инициируется на основе программы карты отдыха для работников. Сформирован перечень мероприятий, на которых основывается государственная программа развития туризма Венгрии (борьба с сезонностью, доступность, поддержка высококачественных услуг, охрана культурного наследия, улучшение образования в области туризма, таргетинг). Исследованы статистические показатели туризма Венгрии.

Ключевые слова: туризм, Венгрия, туристические потоки, государственное управление, показатели.

Hungary has a good place in the world tourism business. The country has a rich heritage and a distinctive culture that makes it an attractive destination for tourists from all over the world. In the ranking of tourism competitiveness of the countries of the world in 2019, Hungary ranks 48th out of 140 countries, which is a positive result. For comparison, according to this rating Ukraine occupies 78th position. Tourism is a strategic sector of Hungary's economy, and the government's goal is to increase the total contribution of Hungarian tourism to GDP by 2030 from the current 10 to 16\% by 2030. Much of the government's attention is focused on Lake Balaton and its environs, where 26 tourism projects have been developed, and new bike lanes, ports, hiking trails and recreational parks are planned. In the future, Hungary intends to become a leading tourist destination in Central Europe by 2030. To this end, the country's government must finance over 260 billion forints (800 million euros) to support tourism development. The Hungarian tax system supports tourism with a reduced VAT rate on accommodation services (18\%, not $27 \%$ on average). The government has developed a new multi-year concept for the tourism industry. It requires significant public investment in the amount of 1 trillion forints, or $\$ 5$ billion. In this ambitious plan, they focus their activities mainly on traditional areas, which have shown high competitiveness in recent years. This is primarily a health tourism with its balneotherapy, which uses the treatment of natural or artificially prepared mineral waters, as well as the organization of international conferences. By the way, Hungary is consistently in the top ten countries, which host a large number of such events. At the same time, Budapest provides the lion's share of the money from such tourism. The tourism industry of the neighboring countries is ahead of the Ukrainian tourism market by development. Therefore, research into the success factors of the Hungarian tourism industry is appropriate and, in the long term, can provide significant strategic guidance for implementation in the domestic tourism industry.

Key words: tourism, Hungary, tourist flows, public administration, indicators.

Постановка проблеми. Угорщина займає хороше місце у світовому туристичному бізнесі. Країна має багату спадщину та самобутню культуру, що робить іiі привабливим місцем для туристів з усього світу. Угорщина має 10 національних парків, 35 зон охорони ландшафту, 145 природних заповідників та 22 винні регіони. Країна займає 47-е місце зі 141 країни в щорічному рейтингу конкурентоспроможності, складеному Всесвітнім економічним форумом. Оцінка Угорщини за глобальним індексом конкурентоспроможності у 2018 р. становила 65,1 за шкалою 0-100 порівняно з 64,3 у 2017 р. Оцінка країни для установ зросла з 54,2 до 55,7, iii показник за інфраструктуру піднявся з 78,4 до 80,7, а показник макроекономічної стабільності залишився на рівні 90,0. У рейтингу туристичної конкурентоспроможності країн світу в 2019 р. Угорщина посідала 48му позицію зі 140 країн, що є позитивним результатом. Для порівняння: згідно з даним рейтингом, Україна займає 78-му позицію. Як бачимо, туристична індустрія країн-сусідів випереджає український туристичний ринок за розвитком, тому дослідження чинників успішності туристичної галузі Угорщини є доцільним і в перспективі може надати суттєві стратегічні орієнтири для імплементації у вітчизняну туристичну індустрію.

Аналіз останніх досліджень і публікацій. Дослідження особливостей сучасної туристичної політики Угорщини знаходять своє відображення у праці Г. Гапоненко, I. Шамара. Автори вважають, що основними туристичними продуктами країни є одноденні тури за покупками із сусідніх країн, багатоденні групові та індивідуальні тури, відвідування термальних курортів (лікувальний туризм), винні тури, сільський туризм, комбіновані тури, відпочинок у замках, мисливські тури, ексклюзивні тури для відпочинку і розваг, проведення семінарів та конференцій для фірм [2, с. 129].

М. Біль досліджував транскордонне співробітництво регіонів України в галузі туризму [1, с. 21-24]. Досвід Угорщини у туристичній сфері як важливого чинника соціально-культурного розвитку держави висвітлено у науковій праці Д. Ткач, В. Цибух [3, с. 48].

О. Федоренко розглядала питання формування та розвитку системи підготовки фахівців у галузі «Туризм» в Угорщині. Автор стверджує, що туризм в Угорщині на сучасному етапі стрімко розвивається, тому підготовка фахівців у цій галузі, яка є відносно новим освітнім напрямом у цій країні, є вимогою сьогодення [4].

Мета статті полягає у розгляді туристичної індустрії Угорщини через призму впливу державної політики на розвиток галузі.

Виклад основного матеріалу. Туризм є стратегічним сектором економіки Угорщини, і мета уряду полягає у тому, щоб до 2030 р. загальний внесок угорського туризму у ВВП збільшиться з нинішніх 10\% до $16 \%$. Значна увага уряду зосереджена на озері Балатон та його околицях, де розроблено 26 туристичних проєктів, планується створити нові велосипедні доріжки, порти, пішохідні маршрути та парки відпочинку.

У перспективі Угорщина має наміри до 2030 р. стати провідним туристичним напрямком Центральної Свропи. Для цього уряд країни повинен фінансувати понад 260 млрд форинтів (800 млн євро) для підтримки розвитку туризму. 
Угорська система оподаткування підтримує туризм зі зниженою ставкою ПДВ на послуги розміщення (18\%, а не в середньому 27\%). Роботодавці отримують користь від пільгових податкових ставок, коли забезпечують стимулювання надання споріднених із туризмом послуг для своїх працівників. Картка відпочинку (Szechenyi SzRC) була введена для промоції вітчизняних туристичних дестинацій. Згідно із цією програмою, зарплата зі зниженою ставкою податку до 1500 євро на рік, з яких 750 євро працівник може використати на проживання, 500 євро - на харчування та 250 євро - на дозвілля. Однією $з$ переваг системи є відносно низький рівень комісії, встановлений на рівні $1,5 \%$, що сплачуються постачальниками послуг після проведення транзакцій.

Уряд розробив нову багаторічну концепцію розвитку туристичної галузі. Для їі втілення потрібні значні державні інвестиції в межах 1 трлн форинтів, або 5 млрд дол. У цьому амбіційному плані спрямовують свою діяльність, головним чином, на традиційних напрямах, які продемонстрували високу конкурентоспроможність протягом останніх років. Це насамперед оздоровчий туризм із його бальнеотерапією, в якій застосовується лікування природними або штучно приготованими мінеральними водами, а також організація міжнародних конференцій. До речі, Угорщина стабільно входить в першу десятку країн світу, які влаштовують у себе велику кількість таких заходів. При цьому левову частку грошових надходжень від подібного туризму забезпечує Будапешт.

Довгостроковими цілями туризму в Угорщині є [7]:

- підвищення конкурентоспроможності за рахунок інноваційного, високоякісного розвитку туристичних продуктів;

- підтримання та створення туристичних робочих місць;

- зміцнення туристичних установ;

- просування Угорщини на нових ринках;

- якісне обслуговування;
- формування унікального профілю Угорщини.

Ключові цілі Концепції розвитку туризму в Угорщині зводяться до: посилення пропозиції туризму шляхом надання фінансової підтримки розвитку підприємництва; поліпшення туристичних послуг (житла та ін.); посилення діяльності органів управління туризму; гармонізація правового регулювання відповідно до директив Європейського Союзу для усунення адміністративних тягарів туристичного бізнесу та спрощення формальностей для туристів, які приїжджають iз країн Свропейського Союзу.

Для досягнення цих цілей було розроблено такі ключові заходи:

1) боротьба із сезонністю: Будапештська кампанія зимових запрошень, яка заохочує туристів до Будапешта в період із листопада по квітень продовжує, бути дуже успішною. Загальний бюджет кампанії становить близько 1 млн євро. Також є кілька внутрішніх ініціатив 3 регіонами та постачальниками послуг, наприклад «Дні відкритих підвалів» та «Тур гусей на день Святого Мартина»;

2) доступність: Угорщина використовує програму «Свропейських напрямів досконалості» (EDEN), щоб привернути увагу до туризму;

3) підтримка високоякісних послуг: створено національну систему торговельної марки. Приєднання до національної системи не є обов'язковим, але це допомагає розрізняти якісних постачальників послуг від некваліфікованих послуг;

4) охорона культурної спадщини: міністерство, що керує туризмом, працює 3 організаціями, відповідальними за культурну спадщину, щоб зберегти та представити іiі широкій громадськості. У 2011 р. парламент прийняв законодавство про світову спадщину, яке узагальнює правила, обмеження та можливості для об'єктів всесвітньої спадщини в Угорщині та забезпечує правову базу для цього;

5) поліпшення освіти в галузі туризму: передбачає низку консультацій між відповідними державними ор-

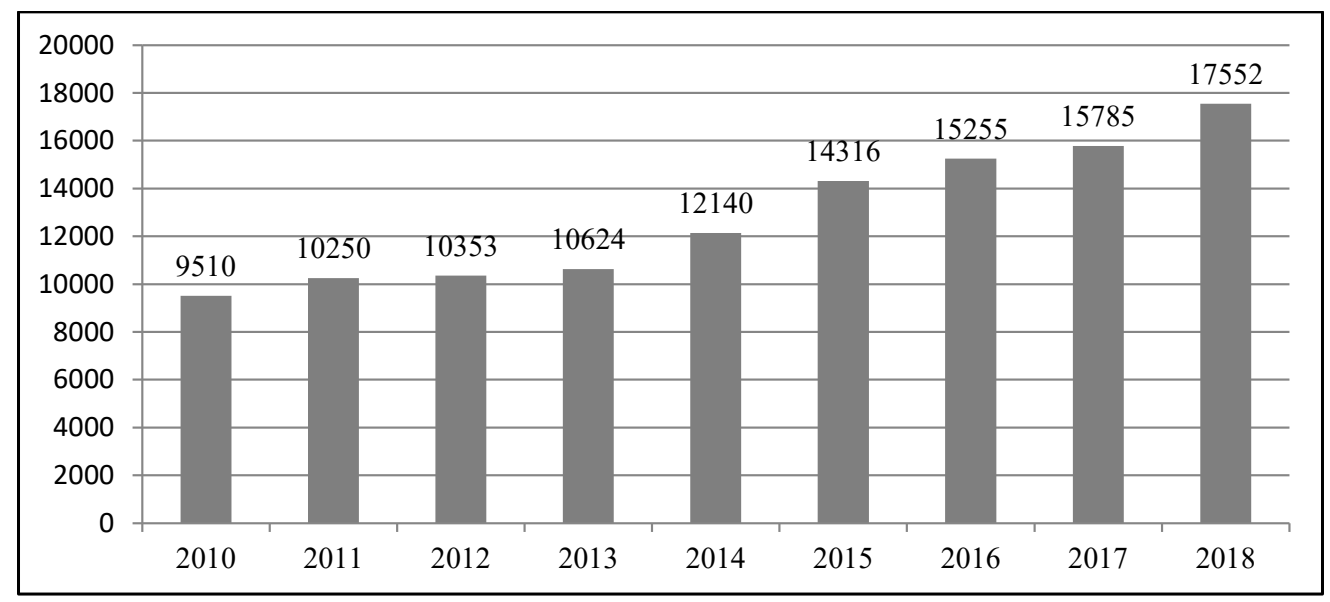

Рис. 1. Кількість туристичних прибуттів в Угорщині

Джерело: складено авторами за даними [6] 


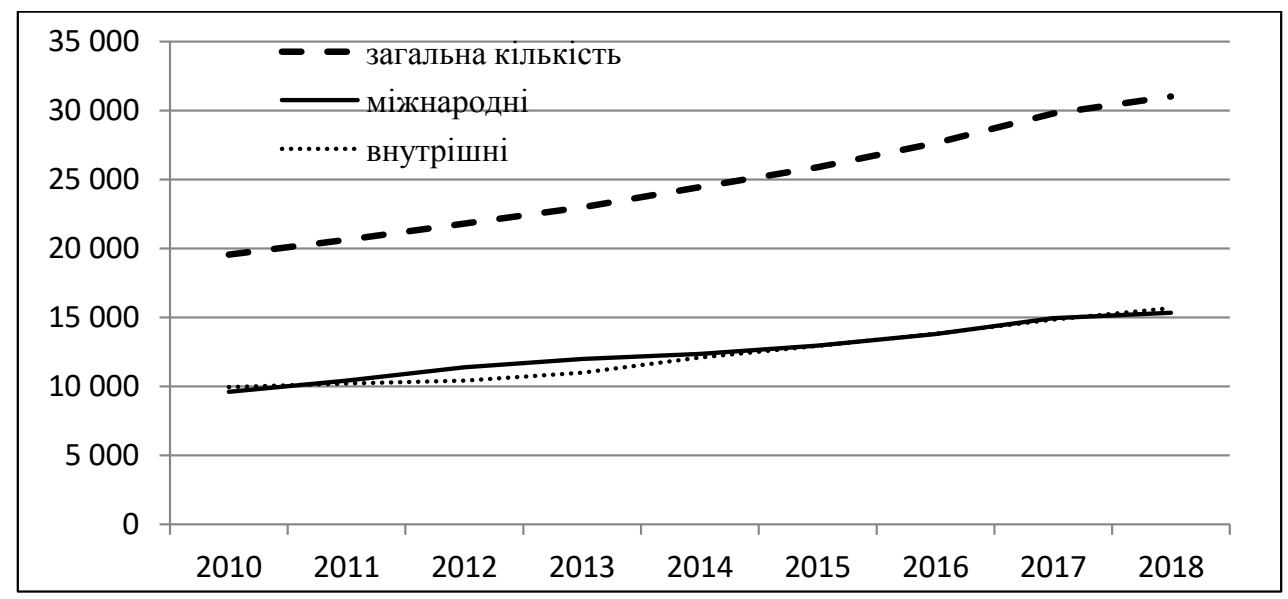

Рис. 2. Кількість ночівель у комерційних засобах розміщення

Джерело: складено авторами за даними [6]

ганами, освітніми інститутами та торговими асоціаціями для розгляду системи професійної підготовки та вищої освіти з метою іiї аналізу у світлі нових тенденцій на ринку [7];

6) таргетинг: просування пропозицій відповідно де сегментації туристів.

За даними Центрального статистичного управління Угорщини, міжнародних туристів, які відвідали країну в 2010 р., було близько 9,5 млн. Надалі з кожним роком даний показник зростав. У 2018 р. кількість туристичних прибуттів становила 17,552 млн осіб (рис. 1). Тобто протягом досліджуваного періоду (2010-2018 рр.) кількість туристів зросла на 8 млн осіб, що свідчить про зростаючу популярність Угорщини на міжнародному туристичному ринку. Найважливішими ініціативними дестинаціями для Угорщини у 2018 р. були Німеччина (2,375 млн) та Румунія (2,370 млн), при цьому близько 2,4 млн прибулих зупинялися принаймні на одну ніч у засобах розміщення. Майже 6,5 млн угорців провели відпустку в Угорщині, що, безумовно, пов'язано зі стимулюванням уряду розвитку внутрішнього туризму.
Поряд зі зростанням кількості іноземних туристів збільшилася й кількість ночівель. У 2018 р. заклади розміщення Угорщини зареєстрували 12,5 млн гостей, що більше на понад 5\% порівняно з 2017 р. Із них майже 50\% були іноземними відвідувачами. Два найпопулярніші напрямки - Будапешт та озеро Балатон. Кількість ночівель у 2018 р. становила майже 31 млн ночей (рис. 2).

При цьому необхідно зауважити, що кількість ночівель у розрізі міжнародних та внутрішніх туристів майже однакова - 15340 та 15671 ночей. Дохід комерційних готелів на тлі зростання ночівель зріс на 9,3\% і становив 510 млрд форинтів.

Основний потік екскурсійних туристичних напрямків в Угорщині припадає, звичайно ж, на столицю країни - Будапешт. Столиця Угорщини приваблює, як правило, поціновувачів архітектури, а також відвідувачів численних музичних фестивалів. До Другої світової війни Будапешт узагалі вважався музичною столицею Центральної та Східної Європи і славився численними театрами, а творець оперет Кальман прославив запаль-

Таблиця 1

Кількість та результативність туристичних агентств та туроператорів [6]

\begin{tabular}{|c|c|c|c|c|c|}
\hline \multirow{4}{*}{ Рік } & \multicolumn{5}{|c|}{ Ліцензовані туристичні агенції та туроператори } \\
\hline & \multirow{3}{*}{ кількість } & \multicolumn{4}{|c|}{ Придбані туристичні пакети } \\
\hline & & \multicolumn{2}{|c|}{ кількість, тис осіб } & \multicolumn{2}{|c|}{ кількість туристських ночей, тис } \\
\hline & & внутрішні & в'їзні & внутрішні & в'їзні \\
\hline 2009 & 1212 & 789 & 610 & 4526 & 1643 \\
\hline 2010 & 1202 & 848 & 676 & 5397 & 1508 \\
\hline 2011 & 1255 & 732 & 690 & 4540 & 1508 \\
\hline 2012 & 1289 & 663 & 727 & 4061 & 1547 \\
\hline 2013 & 1303 & 523 & 686 & 3068 & 1402 \\
\hline 2014 & 1318 & 655 & 819 & 4069 & 1457 \\
\hline 2015 & 1354 & 658 & 881 & 3971 & 1609 \\
\hline 2016 & 1245 & 617 & 857 & 3314 & 1490 \\
\hline 2017 & 1073 & 629 & 929 & 3567 & 1771 \\
\hline 2018 & 1064 & 782 & 1178 & 4351 & 1832 \\
\hline
\end{tabular}


ні угорські мелодії на весь світ [2, с. 128]. Невеликі угорські міста також можуть бути дуже цікавими (Егер, Дебрецен, Хевіз).

Будапешт був визнаний найкращим європейським напрямком у 2019 р. У рамках конкурсу «Найкраща європейська дестинація 2019 року» понад 15 млн мандрівників проголосували за улюблені європейські напрямки, де Будапешт завоював перше місце. Різдвяний ринок Будапешта був визнаний найкрасивішим в Свропі, випередивши новорічні ярмарки Відня, Брюсселя, Праги.

Угорська столиця отримала загалом 62128 голосів, жоден інший попередній переможець не отримав стільки голосів 3-за кордону, як Будапешт, оскільки 77\% голосів подали з інших країн. До цього списку також увійшли Афіни, Флоренція, Братислава, Мец та Париж. Наймодніші напрямки в Свропі мають право відображати назву «Найкраща європейська дестинація» у своєму маркетингу. Міста отримують промоцію протягом року на вебсайті European Best Destinations, у міжнародній пресі та на численних платформах соціальних медіа та туристичних порталах. За даними European Best Destination, перемога в конкуренції суттєво впливає на зростання туристів (16\% приросту туризму для Порту, нагородженого в 2017 р., 13\% - для Бордо, який був відзначений у 2015 р.) [5].
Саме за рахунок туризму в Угорщині живе весь малий бізнес, а це понад 90\% усіх підприємств, що працюють у країні. Але переважно чисельність кожного підприємства не перевищує п'яти-семи осіб. У 2018 р. було 1064 ліцензованих туристичних агенцій та туроператорів (табл. 1).

Висновки. Таким чином, можемо підсумувати, що уряд просуває декілька ініціатив щодо десезоналізації туристичних потоків. Найуспішнішою є кампанія «Будапешт на зиму запрошує», яка спрямована на збільшення туристичних потоків у столиці протягом зимового періоду за допомогою декількох акцій та вигідних туристичних карток. Сектор туризму, згідно з поточними прогнозами, до 2030 р. становитиме 16\% угорського ВВП. Це амбітна мета, але угорський уряд зробив іiі пріоритетним завданням. У країні відбудеться реалізація майже 1000 проєктів розвитку туризму в усій країні (засоби розміщення, ресторани, атракціони та інфраструктура). У 2018 р. кількість туристичних прибуттів становила 17,552 млн осіб, що свідчить про зростаючу популярність Угорщини на міжнародному туристичному ринку. Найважливішими ініціативними дестинаціями для Угорщини були Німеччина (2,375 млн) та Румунія (2,370 млн). Майже 6,5 млн угорців провели відпустку в Угорщині, що, безумовно, пов'язано зі стимулюванням уряду розвитку внутрішнього туризму.

\section{Список літератури:}

1. Біль М. Транскордонне співробітництво регіонів України в галузі туризму: сучасний стан та основні напрямки розвитку. Демократичне врядування. 2008. Вип. 2. С. 21-24.

2. Гапоненко I.I., Шамара I.М. Особливості туристичної політики Угорщини. Вісник Харківського національного університету ім. В.Н. Каразіна. 2013.№ 1086. С. 126-130.

3. Ткач Д.І., Цибух В.І. Туризм як важливий чинник соціально-культурного розвитку держави (на прикладі досвіду Угорщини та Греції). Наукові пращуі МАУП. 2016. Вип. 50. С. 48-52.

4. Федоренко О. Організація підготовки спеціалістів напряму «Туризм» в Угорщині. Порівняльно-педагогічні cmydii.. 2011. № 3-4 URL : http://pps.udpu.edu.ua/article/viewFile/18638/16382 (дата звернення: 02.04.2020).

5. Budapest Wins Best European Destination 2019 Title. URL : https://hungarytoday.hu/budapest-wins-best-europeandestination-2019-title/ (дата звернення: 22.03.2020).

6. Hungarian Central Statistical Office. URL : https:/www.ksh.hu/stadat_annual_4_5(дата звернення: 10.04.2020).

7. OECD countries profiles - Hungary. URL : file:///C:/Users/user/Downloads/Hungary.pdf (дата звернення: 02.04.2020).

\section{References:}

1. Bilj M. (2008) Transkordonne spivrobitnyctvo reghioniv Ukrajiny v ghaluzi turyzmu: suchasnyj stan ta osnovni naprjamky rozvytku [Cross-border cooperation of regions of Ukraine in the field of tourism: current state and main directions of development]. Demokratychne vrjaduvannja: Naukovyj visnyk, no. 2. pp. 21-24.

2. Ghaponenko I. I., Shamara I. M. (2013) Osoblyvosti turystychnoji polityky Ughorshhyny [Features of Hungary's tourism policy]. Visn. Kharkiv. nac. un-tu im. V. N. Karazina, no.1086. pp. 126-130.

3. Tkach D. I., Cybukh V. I. (2016) Turyzm jak vazhlyvyj chynnyk socialjno-kuljturnogho rozvytku derzhavy (na prykladi dosvidu Ughorshhyny ta Ghreciji). [Tourism as an important factor of socio-cultural development of the state (based on the experience of Hungary and Greece)]. Naukovi praci MAUP, no. 50. pp. 48-52.

4. Fedorenko O. (2011) Orghanizacija pidghotovky specialistiv naprjamu «Turyzm» v Ughorshhyni [Organization of Training of Tourism Specialists in Hungary]. Porivnjaljno-pedaghoghichni studiji, no. 3-4. Available at: http://pps.udpu.edu.ua/article/viewFile/18638/16382 (accessed 02 April 2020).

5. Budapest Wins Best European Destination 2019 Title. Available at: https://hungarytoday.hu/budapest-wins-best-european-destination-2019-title/ (accessed 22 March 2020).

6. Hungarian Central Statistical Office. Available at: https://www.ksh.hu/stadat_annual_4_5 (accessed 10 April 2020).

7. OECD countries profiles - Hungary. Available at: file:///C:/Users/user/Downloads/Hungary.pdf (accessed 02 April 2020). 